\title{
Past, present, and future of forest accounting: an overview of the French experience
}

\author{
Alexandra Niedzwiedz • Claire Montagné-Huck
}

Received: 17 April 2014 / Accepted: 8 July 2014 /Published online: 31 July 2014

(C) INRA and Springer-Verlag France 2014

\begin{abstract}
- Aims This paper reminds the historical context of the development of the European framework for forest accounting and claims in favor of a better integration of economic and environmental issues in a consistent accounting framework.

- Context Few articles are available on this topic, especially about development on forest accounting in France.

- Method The French experience in this field is presented as expression of importance and difficulties related to this exercise. - Conclusion Discussion is open on broader international theoretical and practical challenges beyond forest accounting.
\end{abstract}

Keywords Integrated environmental and economic accounting $\cdot$ Forest $\cdot$ Forestry $\cdot$ France

\section{Introduction}

Forests, like all ecosystems, must be sustainably managed if they are to be transmitted to future generations. However, how can we effectively manage what we do not (or only poorly) know? Environmental accounting (EA) was thus introduced

Handling Editor: Marc Hanewinkel

Contribution of the co-authors Alexandra Niedzwiedz and Claire Montagné-Huck gathered the references and used their own experience in forest accounting. A Niedzwiedz wrote the first draft and Claire Montagné- Huck proofread this draft. Both contributed to modifications, acronym harmonization and editorial corrections.

A. Niedzwiedz $(\bowtie) \cdot C$. Montagné-Huck

AgroParisTech-INRA, UMR356 Laboratoire d'Economie Forestière,

14, rue Girardet CS 14216, 54000 Nancy, France

e-mail: alexandra.niedzwiedz@nancy.inra.fr

C. Montagné-Huck

e-mail: claire.montagne@nancy.inra.fr

A. Niedzwiedz $\cdot$ C. Montagné-Huck

INRA-AgroParisTech, UMR 356 Laboratoire d'Economie

Forestière, 14, rue Girardet CS 14216, 54000 Nancy, France in the 1990s to address this question, with the aim of quantifying environmental issues related to human activities. Such a framework helps to organize statistical data in order to develop coherent indicators and descriptive statistics, and offers more effective monitoring of the interactions between the economy and the environment to be integrated into the decision-making processes (UN 2003). EA allows the assessment of all natural stocks, variations due to natural or human activities, and expenditures for resource protection, and provides indices for a sustainable economy (Goudie and Cuff 2001; Goio et al. 2008). Faced with the necessity of introducing sustainable development into national economies, this tool, as well as previously acquired experience, should be used to support the development of integrated economic and environmental monitoring of practices in effect. The main interest of EA is that economic pressures on the environment and environmental contributions to the economy can be jointly measured in both physical and monetary terms.

Given that forests interact with the economy in more ways than probably any other resource, they were quickly included in EA (Vincent 1999), and forests are now, by far, the most extensively studied renewable resource in EA (Huhtala et al. 2003; Goio et al. 2008). Nevertheless, the forthcoming challenges for EA consist, above all, in a complete and consistent implementation and an effective use by (supra) national authorities, in particular. Once this has been done, taking the value of non-market forest amenities into account could be the next step towards an environmentally adjusted national income.

In this paper, we present past and current developments of European forest accounting. In particular, we focus on the French experience and use it as a basis to analyze how the European forest accounting framework could be improved. Finally, we ask ourselves to what extent this collective work on economic-environmental accounting could lead to a green GDP.

First, a brief history of forest accounting and the French involvement in the field are presented. Second, we focus on some key issues that the European member states have to face 
when dealing with forest-related EA. Finally, we conclude by analyzing the importance of the European environmental strategy.

\section{Accounting for forests: a historical perspective}

\subsection{History of forest accounts}

The historical implementation of national accounting at the international, European, and national levels is neither a linear nor a pyramidal stepwise development. Instead, initiatives to improve the functioning of accounting standards at different levels are interrelated and closely intertwined. Thus, developments at one level often have an impact on the other two. National frameworks obviously benefit from and integrate international improvements, but international frameworks also benefit from infra-level pilot case studies and experiences (Fig. 1).

As far back as 1947, the United Nations Statistical Commission (UNSC) emphasized the need for statistical standards for the compilation and updating of comparable statistics in support of a large array of policy needs (UN 1947). The 1953 System of National Accounts (SNA, last revision in 2008) was published under the auspices of the UNSC with the aim to provide a comprehensive and conceptual accounting framework for compiling macroeconomic statistics that would make it possible to assess the performance of an economy (activity, wealth, and the general structure of the economy). However, based on monetary flows, the central framework fails to measure all the costs and benefits of human activities, i.e., the sustainable development of the economy. This crucial limit of the SNA was internationally recognized by the end of the 1980s (e.g., the Brundtland report-WCED 1987), and a satellite approach, known as the System of Environmental Economic Accounting (SEEA), was developed to address this problem. It extends the analytical capacity of national accounts to the monitoring of the interactions between the economy and the environment, without overburdening the central framework of the SNA. It is a mixture of national accounts and environmental statistics (UN 1993, 2003, 2012). The SEEA monitors the stock of natural resources, the flows of materials and energy, and environmental economic data that may be expressed in either physical or monetary terms, or both. Despite the importance of forests as natural resources, no dedicated accounts existed in the SEEA until preliminary work was done in the mid 1990s. The first manual for environmental and economic accounts for forestry (EEAF) was published by the Food and Agriculture Organization (FAO) of the United Nations (Lange 2004).

As for European countries, the European System of Accounts (ESA) is a coherent system of national accounts developed since the 1970s (last revision in 2010) by the statistical office of the European Union (Eurostat), and is fully consistent with the United Nations' SNA. The European Economic Accounts for Forestry (EAF) has been published since 1969 in the form of ESA satellite accounts. The focus is on accounting for production processes and primary income generated by forests and other wooded lands.

Concomitantly, with the implementation of the SEEA, a task force devoted to forestry accounting was created in Europe. Several countries, France included, worked together to build a framework for Integrated Environmental and Economic Accounting for Forests (IEEAF), based on the principles of EA, comprising indicators for major forest services as well. The objective of this framework is to consistently link the flow accounts to the forest balance sheet in physical and monetary terms (Eurostat 1999).

Initially focused on natural resource depletion, the IEEAF has been increasingly used as a sustainability measurement tool, particularly when, in 2006, the IEEAF scheme was substituted for the EAF (Sekot 2007). At the same time, to avoid redundancy and the duplication of information, some of the 20 initial IEEAF tables were removed, and pure environmental information was integrated into the indicators of the Ministerial Conference on the Protection of Forests in Europe (MCPFE, also known as Forest Europe). The IEEAF is currently made up of 13 interdependent yearly tables (Table 1) that are provided by member states on a voluntary basis.

Except for the carbon and defoliation tables, all of the IEEAF accounts are presented in both physical and monetary units. Although these tables are interdependent (Fig. 2), the economic account for forestry and logging (T3c) is the only single table considered as a priority and published by Eurostat.

\subsection{French involvement}

France has long been involved in the development of a national accounting framework, independently of international frameworks and consistent with them since the end of the 1970s (Vanoli 2002). This specific experience in the field often leads France to anticipate structural reforms and to be a major contributor to international debates. For example, the "Comptes de patrimoine" (that integrate environmental concerns) have existed in France since the early 1980s.

France, represented by the Laboratory of Forest Economics $(\mathrm{LEF})^{1}$, has been involved in the development of forest accounting since the first Eurostat task force (1995) and the pilot IEEAF application (Peyron 1998; Tessier and Peyron 1998; Eurostat 1999). As of 1998, LEF was delegated by the French Ministry of the Environment to work on the IEEAF in conjunction with other French organizations such as the National Institute of Geographic and Forest Information (IGN), the

\footnotetext{
${ }^{1}$ LEF is a joint research unit (INRA \& AgroParisTech) located in Nancy (France). http://www.nancy.inra.fr/lef_eng/
} 
Fig. 1 Timeline of forestry accounting

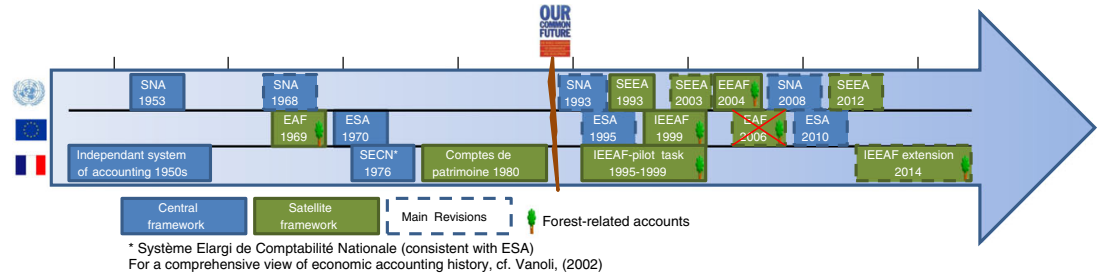

statistical office of the Ministry of Agriculture (Service de la Statistique et de la Prospective; SSP), and the National Institute of Statistics and Economic Studies (INSEE), to gather relevant data, to adapt methods in order to fulfill Eurostat's requirements, and to analyze the results. These organizations are members of the French IEEAF steering committee.

Since 2000, France has provided the entire set of yearly IEEAF tables. Specific methods are often needed to perform this task. For example, LEF has developed a way to estimate a yearly update of the standing timber stock that could not be provided by the national forest inventory (until the implementation of a new forest inventory method in 2005). In spite of the lack of timber prices, LEF has also implemented an original method to estimate the average stumpage price to value the stock of standing timber (Tessier and Peyron 1998). At the same time, LEF works together with other IEEAF stakeholders and contributes to the evolution of the
IEEAF by sharing experiences on methodological issues with the Eurostat Forestry Statistics Office.

Because of its annual accounting period, the IEEAF is of great interest for national policy makers. It is used by national accountants as well as by the government to monitor forestry activities. It provides information that is not available elsewhere at this level of detail. The main advantage of this tool is to offer specific valuations that the national accounting system is not able to implement. Forest accounts are also useful for national and international reporting on forest economic-related issues. Therefore, indicators of sustainable forest management (Forest Europe) require information from the IEEAF concerning some economic aspects such as forestry income and productive functions of forests (MAAPRAT 2011). Whereas indicators of sustainable management focus on environmental and ecological issues, forest accounts are the link between the central accounting system and forest resource monitoring. Therefore, analyses in

Table 1 List of IEEAF tables

\begin{tabular}{|c|c|c|c|c|}
\hline Theme & Table & Label & Variables & Unit \\
\hline \multirow[t]{5}{*}{ Forest resource } & 1a & Area of wooded land & $\begin{array}{l}\text { Opening stock, changes due to economic activities, } \\
\text { natural changes, other changes, closing stock }\end{array}$ & На \\
\hline & $1 b$ & Value of wooded land & $\begin{array}{l}\text { Valued stocks and flows from T1a and a "revaluation" } \\
\text { term }\end{array}$ & Euro \\
\hline & $2 \mathrm{a}$ & Volume of standing timber & $\begin{array}{l}\text { Opening stock, gross increment, mortality, feelings, } \\
\text { other changes and closing stock }\end{array}$ & $\mathrm{M}^{3}$ \\
\hline & $2 b$ & Value of standing timber & $\begin{array}{l}\text { Valued stocks and flows from T2a and a 'revaluation' } \\
\text { term }\end{array}$ & Euro \\
\hline & $2 \mathrm{c}$ & Defoliation & Percentage of trees defoliated over $25 \%$ & $\%, \mathrm{~m}^{3}$ \\
\hline \multirow[t]{2}{*}{ Economic accounts } & $3 a$ & Output related to wooded land & $\begin{array}{l}\text { Value of goods (wood and other forest products), and } \\
\text { services by industry and type of output }\end{array}$ & Euro \\
\hline & $3 \mathrm{c}$ & $\begin{array}{l}\text { Economic accounts for forestry } \\
\text { and logging }\end{array}$ & $\begin{array}{l}\text { Production, intermediate consumption, value added and } \\
\text { other accounting aggregates }\end{array}$ & Euro \\
\hline \multirow[t]{4}{*}{ Supply-use tables } & $4 \mathrm{a}$ & Physical table: use & $\begin{array}{l}\text { Capital formation, export, intermediate and final } \\
\text { consumption for all forest-related products, from } \\
\text { growing standing timber to final products }\end{array}$ & Tons, $\mathrm{m}^{3}$ \\
\hline & $4 b$ & Physical table: supply & $\begin{array}{l}\text { Production, import for all forest-related products, from } \\
\text { growing standing timber to final products }\end{array}$ & Tons, $\mathrm{m}^{3}$ \\
\hline & $5 \mathrm{a}$ & Monetary table: use & $\begin{array}{l}\text { Capital formation, export, intermediate and final } \\
\text { consumption for all forest-related products, from } \\
\text { growing standing timber to final products }\end{array}$ & Euro \\
\hline & $5 b$ & Monetary table: supply & $\begin{array}{l}\text { Production, import for all forest-related products, from } \\
\text { growing standing timber to final products }\end{array}$ & Euro \\
\hline \multirow[t]{2}{*}{ Carbon } & $\mathrm{F} 1$ & Carbon balance for woody biomass & $\begin{array}{l}\text { Opening and closing stock, gross increment, removals, } \\
\text { other changes in forest carbon stock }\end{array}$ & Tons of carbon \\
\hline & $\mathrm{F} 2$ & Carbon balance for the forest ecosystem & $\begin{array}{l}\text { Opening and closing stock, change in carbon stock per } \\
\text { ecosystem compartment }\end{array}$ & Tons of carbon \\
\hline
\end{tabular}


IEEAF: Relations between tables

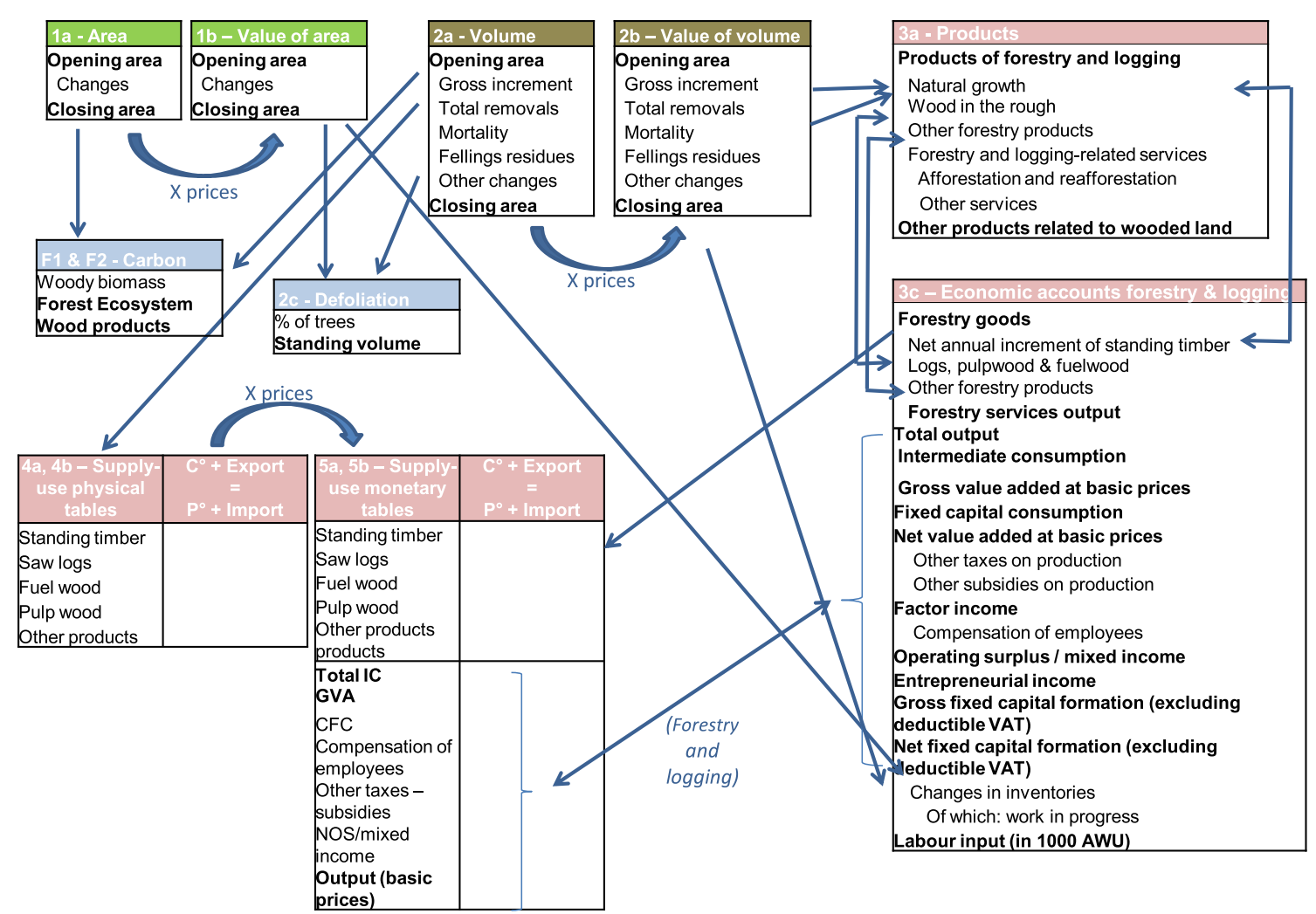

Fig. 2 Relationships between IEEAF tables

both physical and monetary terms are only possible through the IEEAF framework. In addition, forest accounts are integrated into the analysis of the multifunctionality of French forests (Berger and Peyron 2005; Merlo and Croitoru 2005; Montagné and Niedzwiedz 2010a, b) and will contribute to the evaluation of the ecosystem and ecosystemic services since they can be implemented at the local scale. However, due to the voluntary basis and the poor awareness of the tool, IEEAF results are often under-used for policymaking, notably at the European level.

\section{Current issues related to the IEEAF}

France, like other European Union (EU) member states, has to face some nonnegligible hurdles concerning IEEAF reporting. However, its long-term and steady involvement in the IEEAF can give weight to its methodological propositions. Problems facing the IEEAF fall into three categories as follows: policy-, methodological-, and data-related.

\subsection{Policy issues}

Forests provide raw material for wood-based industries and various services to society at large. Although the EU has no proper forests or forestry policy, forest issues are strongly related to rural development policy, renewable energy policy, and climate action. These policy fields require reliable data of which forest and wood are a part.

In this way, the IEEAF is able to provide environmental and economic forest-related indicators for policy makers at the European as well as the national level. It can help to determine a true value of forest contribution as well as to measure the impacts of non-forestry policies on the forest sector (Lange 2004). However, in order to obtain a more efficient result, the aims of such a framework have to be clearly specified. A clarified EU strategy in terms of statistics for policy implementation should lead to the selection of priority indicators and will help to avoid redundancies (and inconsistencies) with other reporting. As underlined during the Eurostat Conference on "Statistics for policy making: Europe 2020," "we need to better measure our natural capital, its ecosystem services, in physical terms, and in monetary terms" (Potočnik 2011). Thanks to its accounting framework, IEEAF reporting has a role to play in this statistical process. This implies that significant work has to be done to define a system of accounts that integrate the productive and nonproductive, priced and non-priced, final and intermediate aspects of ecosystem services in a complete and reliable way. 
In this perspective, current endeavors at the European level aim to take the value of the forest per se into account in the National Accounts balance sheets for nonfinancial assets. On the one hand, in the central framework, only stocks and natural growth that are managed and controlled by institutional units are considered in terms of production. Therefore, the treatment of forests and timber stocks depends on their characteristics. On the other hand, the satellite system includes all forests that provide environmental services. In principle, forest land and standing timber should be registered as two separate values. The stock of forest land, in terms of economic use, is part of the "Land" asset in the National Accounts, whereas the timber stock is part of the "Cultivated biological resources." Nonetheless, it is often difficult to separate these two elements in practice since it is assumed that they form a composite asset referred to as "forest estate" (UN 2003). Therefore, as of 1 September 2014, in the case of forests for wood production, it will be mandatory for member states to register the land underlying the forests under "Land" and the tree stands under "Inventories" (Eurostat 2014). IEEAF tables on the value of forest ( $1 \mathrm{~b}$ and $2 \mathrm{~b}$ ) have been proposed by Eurostat as a good starting point for this introduction. As proposed by the Eurostat forestry group, the integration of the IEEAF tables into the European regulation system would enhance its credibility. That way, the IEEAF framework, of which some tables already fully correspond to some 2012 SEEA tables, could easily find its legitimate place. Moreover, when associated with complementary international reporting such as the Joint Forest Sector Questionnaire (JFSQ), dedicated to wood material, or the Sustainable Forest Management Indicators, the EU would have a more overall and consistent view of the activities and values related to forests. As a result of this increased visibility, IEEAF tables would be easier to complete by member states, regardless of the nature, voluntary or mandatory, of the exercise. The European Commission (EC) could then consider a more comprehensive and periodic diffusion of IEEAF methods and results. Either way, the methodological issues remain a key point for the ongoing improvement and the use of such a tool.

\subsection{Methodological issues}

International organizations have launched various forestrelated statistics processes within a large-scale framework: Forest Europe has monitored the pan-European indicators for sustainable forest management (MCPFE 2003, 2007; Forest Europe 2011), and the FAO has published three issues (FAO 2011 is the latest) of the Forest Resources Assessment (FRA) as well as an annual questionnaire (JFSQ) since 1999 (FAO 2003). All of these endeavors contribute to improving our knowledge about the forest and the forest sector at the national and international levels. However, each process has its own terms, definitions, and time reference (Ståhl et al. 2012). Despite the implementation of harmonized definitions of forest land, the information requested about wood volumes may be different depending on the process (stems or stems and large branches; over or under bark volumes). Such dissimilarities may burden the process of reporting for suppliers and create deep misunderstandings among users. For example, roundwood removals computed for the JFSQ are not directly comparable to those of the IEEAF. This difference could be explained both by the definition of terms and by the units used by each system (over/under bark). "This reduces the comparability and interoperability of the different data, on the one hand, and imposes higher workloads for the reporters, on the other." (Eurostat 2011a).

Moreover, some information is redundant within the different processes. In addition to unit and definition problems, this can add confusion for the users. Furthermore, organizations involved in these processes do not necessarily use the same methods to provide information for the indicators. Consequently, the differences between all the results for one indicator might not be clearly understandable, even for wellinformed users. Current discussions (Eurostat 2011a) propose using an adaptation of the current IEEAF tables on forest area and wood volume to cover all the reporting requirements on forest resources for the FAO, Forest Europe, the LULUCF (Land Use, Land-Use Change, and Forestry), and the Organization for Economic Cooperation and Development (OECD). This adaptation should also try to avoid the overlap between forestry and agro-forestry areas that has frequently led to double-counting in international surveys. At the European level, this development means all members should agree on such a proposal.

All these discussions could also affect the carbon part of the IEEAF: Isn't the carbon balance for woody biomass redundant with the C1.4 Forest Europe indicator? What is the most relevant information required for climate policies?

Carrying out the aforementioned developments requires the involvement of many task forces from all of the forestry statistical processes. First of all, convincing stakeholders of the usefulness of accounting systems such as the IEEAF may require the improvement of the methods used and the wide diffusion of IEEAF results. Current efforts devoted to forest land and timber may contribute to reaching this target. Thus, the exchanges between organizations and national stakeholders are consistently contributing to European discussions aimed at reaching a global agreement on methodological issues. This will be the opportunity to release a new methodological guideline, updating the 2002 version (Eurostat 2002).

\subsection{Data issues}

Beyond political and methodological issues, some datarelated issues still occur. They may concern the characteristics of national statistics or national specificities that are not consistent with wider European requirements. 
The IEEAF tables, like most economic and environmental accounts, are yearly-based. However, this periodicity is not common in forestry. Not all national forest inventories across Europe are able to provide data on a yearly basis. Therefore, special efforts are often needed to develop annual running estimates. Forest accountants should work with forest inventory services and follow the European recommendations about the most relevant methods to be used (Eurostat 2014). Eurostat also suggests close cooperation between national organizations for the annual balance sheets in monetary terms, since they are part of the national accounts transmitted.

Nevertheless, the IEEAF framework could provide the opportunity to harmonize forest inventories within the EU in terms of definition, method, and data released. This kind of long-term improvement, in spite of the fact that it requires costly developments, will lead the EU to raise the forest information level. Thus, misinterpretation and errors in reporting could be limited by using a common basis. France, a country that has been involved for a long time now, was qualified as a "good student" in IEEAF reporting (Eurostat 2011b). This is the result of considerable efforts and important groundwork, supported by the implementation of a new forest inventory method that produces more accurate data on forests available for wood supply and topical needs, such as windfall woods.

Eurostat pointed out the importance of "developing and ensuring the data availability for IEEAF" (Eurostat 2007). In some cases, adaptation could be sufficient to overcome some difficulties. For example, relevant national issues probably take priority over global issues in national surveys and inventories. Some national statistical services are consequently not used to produce indicators that may appear as not relevant at the national scale. Conversely, some countries may develop a specific survey to take some interesting points into account. In these cases, adding new variables to a survey or using existing forest models to estimate some measures could be a valuable improvement for reporting, without making significant changes in a national statistical system.

\section{Conclusion}

In this article, we highlight the interest over the past decades in IEEAF reporting. The ongoing discussions at the international and national levels reflect the extent to which this is a key issue in forest and forestry statistics that could be part of the new EU forest strategy as a tool for improving the knowledge base and fostering coordination and communication about forests and forest-based sectors (EC 2013).

We present here the French involvement and experience in the IEEAF and underline some important issues related to European policy, methods, and data requirements. The current and potential applications for policy making are discussed.
Improving IEEAF reporting requires collective discussions on both the methods and objectives of this tool. We need efficient measurement of the economic, social, and environmental values of forest resources. At a global level, the best way to enhance the work of each country is to first harmonize all the questionnaires - terms, definitions, units - related to forest and wood, and to clarify their objectives. Second, the EU should help countries to develop suitable methods. Thus, the IEEAF will be able to become the reference tool, providing relevant and annual data, consistent with national accounts and economic theory.

Moreover, there is a substantial current interest in expanding accounting systems to include non-priced social and ecological forest services (Edens and Hein 2013). However, researchers are faced with a number of challenges: to reach a consensus about the definition of non-priced services, to remedy physical and monetary data deficits, and to develop valuation techniques that ensure the homogeneity, comparability, durability, significance, and robustness of such data (Vincent 1999; Kriström and Skånberg 2001; Adamowicz 2003; Sekot 2007; Campos and Caparrós 2009; Goio et al. 2008). This could eventually allow the computation of new indicators based on IEEAF data, which could bring a green aspect to the national wealth.

In order to play a significant role as a tool for inducing trends towards ecological, economic, and socially-sound policy making, forest resource accounting requires a shift in ways of thinking, a call for further multidisciplinary research, particularly in the field of nonproductive ecosystem services, as well as the active promotion of its advantages by powerful actors and international institutions.

Acknowledgments This work was funded by the French Ministry for Ecology, Sustainable Development and Energy-Statistical Office (MEDDTL-SOeS). We would also like to thank the IGN and other steering committee members for data and methodological discussions. The UMR Economie Forestière is supported by a grant overseen by the French National Research Agency (ANR) as part of the "Investissements d'Avenir" program (ANR-11-LABX-0002-01, Lab of Excellence ARBRE). We would like to thank the anonymous reviewers for their suggestions and comments.

\section{References}

Adamowicz W (2003) Economic indicators of sustainable forest management: theory versus practice. J For Econ 9:27-40

Berger A, Peyron JL (2005) Les multiples valeurs de la forêt française. Institut français de l'environnement (IFEN), Les Données de l'environnement, $\mathrm{n}^{\circ} 105$, août 2005 , Orléans

Campos P, Caparrós A (2009) Can we use non-market valuation techniques in green national accounting applied to forests? Austrian J For Sci 126:53-74

Edens B, Hein L (2013) Towards a consistent approach for ecosystem accounting. Ecol Econ 90:41-52

European commission (2013) A new European forest strategy: for forest and the forest-based sector. Brussels

Eurostat (1999) The european framework for integrated environmental and economic accounting for forests: Results of pilot applications. 
Luxembourg, Office for Official Publications of the European Communities. Catalogue number CA-22-99-329-EN-N

Eurostat (2002) The European framework for integrated environmental and economic accounting for forests - IEEAF. Luxembourg, Office for Official Publications of the European Communities. Catalogue number KS-BE-02-003-EN-N

Eurostat (2007) Accounting for the Environment-The European Development. European Commission. 5p. http://www.beyond-gdp. eu/download/bgdp-bp-mollgaard.pdf

Eurostat (2011a) Forestry Statistics policy review 2011. Environmental and forestry statistics Unit, Working paper, Doc. FO/2011WG/5

Eurostat (2011b) Forestry Statistics: Integrated environmental and economic accounting for forests. Environmental and forestry statistics Unit, Cover note to the delegates of the Working Group on Forestry Statistics of 16-17 November 2011, Doc. FO/2011WG/6 http://epp. eurostat.ec.europa.eu/cache/ITY_OFFPUB/KS-31-11-137/EN/KS31-11-137-EN.PDF

Eurostat (2014) Reflections on the future of Eurostat's work on integrated environmental and economic accounting for forests. Forestry Statistics and Accounting Working Group. 22-23 January 2014. Working paper, Doc. FO/2014WG/5.0

FAO (2003) Forestry reporting requests by FAO. FRA Working Paper 67

FAO (2011) Global forest resource assessment 2010 - Main report. FAO Forestry paper 163 . Rome

Forest Europe (2011) Ministerial Conference on the Protection of Forests in Europe Conference Proceedings, Oslo, 14-16 June 2011

Goio I, Gios G, Pollini C (2008) The development of forest accounting in the province of Trento (Italy). J For Econ 14:177-196

Goudie A, Cuff DJ (2001) Encyclopedia of global change: environmental change and human society. Oxford University Press

Huhtala A, Toppinen A, Boman M (2003) When the theory is not enough-valuation of forest resources with "efficiency" prices in practice. J For Econ 9:205-222

Kriström B, Skånberg K (2001) Monetary forestry accounting including environmental goods and services. Investigación Agraria: Sistemas y Recursos. Fuera de Serie 1-2001

Lange GM (2004) Manual for environmental and economic accounts for forestry: a tool for cross-sectoral policy analysis. Food and Agriculture Organisation of the United Nations (FAO). Forestry department. Working Paper. Rome. http://www.fao.org/docrep/ 007/j1972e/j1972e00.htm\#TOC

Merlo M, Croitoru L (eds) (2005) Valuing Mediterranean forests: towards total economic value. CABI Publishing, Wallingford

MCPFE (2003) Fourth Ministerial Conference on the Protection of Forests in Europe - Conference Proceedings, Vienne, Autriche, 28-30 avril 2003. Vienne, Autriche, MCPFE Liaison Unit

MCPFE (2007) Work Programme. Pan-European Follow-Up of the 5th Ministerial Conference 5-7 November 2007, Warsaw
Ministère de l'Agriculture, de l'Alimentation, de la Pêche, de la Ruralité et de l'Aménagement du Territoire (MAAPRAT) (2011) Les indicateurs de gestion durable des forêts françaises métropolitaines - Edition 2010

Montagné C, Niedzwiedz A (2010a) Comptes intégrés économiques et environnementaux de la forêt en France - Première Partie. Revue Forestière Française LXII:541-550

Montagné C, Niedzwiedz A (2010b) Comptes intégrés économiques et environnementaux de la forêt en France - Seconde Partie. Revue Forestière Française LXII:625-640

Peyron JL (1998) Elaboration d'un système de comptes économiques articulés de la forêt au niveau national. Thèse, Nancy (FRA), Université Nancy 2. ENGREF, Nancy (FRA)

Potočnik J (2011) Measuring green growth and natural capital - the importance of statistics in environment policy. Speech, in speech during the Eurostat Conference on "Statistics for policy making: Europe 2020" on 10 March 2011 in Brussels. http://europa.eu/rapid/ pressReleasesAction.do?reference $=\mathrm{SPEECH} / 11 / 164 \&$ format $=$ PDF\&aged $=0$ \&language $=$ EN\&guiLanguage $=e n$

Sekot W (2007) European forest accounting - general concepts and Austrian experiences European Journal of Forest Research, 126: 481-494; ISSN 1612-4669

Ståhl G, Cienciala E, Chirici G, Lanz A, Vidal C, Winter S, McRoberts RE, Rondeux J, Schadauer J, Tomppo E (2012) Bridging national and reference definitions for harmonizing forest statistics. For Sci 58:214-223

Tessier A, Peyron JL (1998) Faisabilité de comptes de la forêt en France. A pilot study for Eurostat and DGI. IFEN and ENGREF Report

United Nations (1947) Measurement of national income and the construction of social accounts. Report of the sub-committee on national income statistics of the League of Nations committee of statistical experts. Studies and reports on statistical methods $n^{\circ} 7$. United Nations Geneva http://unstats.un.org/unsd/nationalaccount/docs/ 1947NAreport.pdf

United Nations (1993) SNA Handbook on Integrated Environmental and Economic Accounting, Statistical Office of the United Nations, Series F, No 61, New York

United Nations (2003) Handbook of National Accounting: Integrated Environmental and Economic Accounting. http://unstats.un.org/ unsd/envaccounting/seea2003.pdf

United Nations (2012) System of Environmental Economic Accounting. Central framework. European Commission, Food and Agriculture Organization, International Monetary Fund, Organization for Economic Cooperation and Development, United Nations, World Bank http://unstats.un.org/unsd/envaccounting/White cover.pdf

Vincent JR (1999) A framework for forest accounting. For Sci 45:552-561

Vanoli A (2002) Une histoire de la comptabilité nationale. La Découverte, Paris

World Commission on Environment and Development (1987) Our common future. Oxford University Press, Oxford 